\title{
Emergency Remote Teaching and Learning in Greek Universities During the COVID-19 Pandemic: The Attitudes of University Students
}

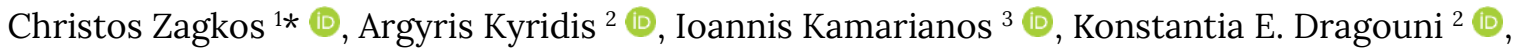 \\ Aggeliki Katsanou $^{2}$ (), Evangelia Kouroumichaki ${ }^{2}$ (), Nikoleta Papastergiou ${ }^{2}$ (), \\ Eleftherios Stergianopoulos 2 (B)
}

\author{
${ }^{1}$ University of Ioannina, GREECE \\ ${ }^{2}$ Aristotle University of Thessaloniki, GREECE \\ ${ }^{3}$ University of Patras, GREECE \\ *Corresponding Author: chzagkos@uoi.gr
}

Citation: Zagkos, C., Kyridis, A., Kamarianos, I., Dragouni, K. E., Katsanou, A., Kouroumichaki, E., Papastergiou, N., \& Stergianopoulos, E. (2022). Emergency Remote Teaching and Learning in Greek Universities During the COVID-19 Pandemic: The Attitudes of University Students. European Journal of Interactive Multimedia and Education, 3(1), e02207. https://doi.org/10.30935/ejimed/11494

\begin{abstract}
Undoubtedly the pandemic of COVID-19 had a great impact globally on our daily activities. Whereas to face this unprecedented situation all the educational institutions were compelled to keep the lessons conducted over the internet. Under the current circumstances this quantitative research detects, describes, and measures attitudes of 807 students of 5 Greek universities towards the distance learning process. The data that was collected by using a 5-point Likert scale reflects the strong agreement of the students that face-to-face teaching cannot be replaced by distance learning, especially when it comes to laboratory training. The consensus is also that remote learning has abased pedagogical relationships between professors and classmates and among the latter as well. Findings indicate that students come to a meeting of minds about the educational inequalities which are worsened by the lack of digital equipment and undeveloped technological infrastructure. Furthermore, this study reveals a correlation between the responses of the sample and their demographic and social characteristics, something that offers possibilities for additional research.

Keywords: distance learning, educational inequalities, COVID-19, remote education, students' attitudes

Received: 4 Nov. $2021 \bullet$ Accepted: 9 Dec. 2021
\end{abstract}

\section{THEORETICAL UNDERPINNINGS}

Recently, and amid the circumstances created due to Coronavirus (COVID-19), new conditions have been established for almost the entire global higher education sector (Crawford et al., 2020). Given the impact of the pandemic crisis (COVID-19) on education, we consider it necessary to focus on two important issues. At first, during the crisis that arose at the end of March 2020, more than 1.5 billion students and youth across the planet have been affected by the school and university lockdown closure, due to the COVID-19 pandemic. UNESCO introduced the terms 'emergency' and 'educational disruption' for the effects of the crisis on educational institutions and systems. Over 100 million teachers and school personnel were impacted by the sudden closures of learning institutions. Today, two-thirds of the world's student population is still affected by full or partial educational institutions closures. In 29 countries, schools remain fully closed. 24 million children and youth are at risk of dropping out (Karalis, 2020; UNESCO Institute for Statistics Data, 2020). Liquidity (Bauman, 2000), and dynamic change have increased especially under the pressure of pandemic crisis' demands for social distancing, a phenomenon that is experienced worldwide (Dhawan, 2020). However, we should note here that like the so-called 'normal circumstances', the digital transformation to remote teaching and digital classrooms, bears and raises a variety of issues on quality, social interaction, data protection, issues which need to be carefully discussed and tackled. The remarks above convey a sense of urgency within academia that pressures students to keep up with changes and raises concerns that some students may be left behind.

The closure of universities created new economic, social and educational phenomena and difficulties that had to be overcome, in order to continue the educational activity. A combination of soft and digital skills is required for educational and pedagogical practices in a complex social and digital universe, where the use and development of electronic means of communication were inevitable (Fotii, 2020). The Vice Chancellor of the Open University (UK) speaking to the University Council, mentioned the following (Jones et al., 2020):

"Most of our students think IM, text and Google are verbs not applications! They expect to be engaged by their environment, 
with participatory, sensory-rich, experiential activities (either physical or virtual) and opportunities for input. They are more oriented to visual media than previous generations -and prefer to learn by doing rather than by telling or reading. They explicitly prefer to discover rather than be told".

It is well known among researchers that technology can facilitate our everyday lives (Dimensional Research, 2018). T he most important benefit of online education for students, under the current circumstances, turned out to be the ability to study in the safety of their own home (Sahbaz, 2020). Also, students listed flexibility as the main advantage of using digital infrastructure for studying (Serhan, 2020). But students' adaptation to distance learning under the pressure of the consequences of the pandemic crisis, cannot be effective in countries that a vast majority of students do not have access to the internet due to technical, pedagogical, and financial or organizational issues (Adnan \& Anwar, 2020). A typical example was the set of the conditions in the southern regions of Italy, where approximately $20 \%$ of the students did not have access to any devices and were excluded from learning, a phenomenon which in turn generates a direct risk of increased adolescent delinquency (Ferraro et.al., 2020). According to the UN, at least 463 million or nearly one-third of students around the globe cannot access remote learning, mainly due to a lack of online learning policies or lack of equipment needed to connect from home. Most students do not have the appropriate connectivity, device, and digital skills required to find and use educational content dependent on technology (UNESCO Institute for Statistics Data, 2020).

Because of these financial and technical obstacles, students are also challenged with electricity interruptions or/and with the storage capacity of their available digital devices. Making these needs meet requires individual or family internet expenses (Rotas \& Cahapay, 2020). Thus, students attending universities in the so-called developing countries, where the technological infrastructure is not very developed, face significant problems due to technological developments in higher education, which are not sufficient for an urgent educational transition (Crawford et al., 2020).

This is the COVID-19 version of the digital breakdown. On the one hand, the middle class is working safely and with access to technology in comfortable homes, and on the other side, students of disadvantaged communities (often ethnic minorities) are unable to access such technology in cramped homes, coupled with the need and requirement to work on-site. Thus, while for the former the conditions of their safe home led to a de-risking COVID-19 situation, for the latter the insecurity and risk increased (Breslin, 2021).

The pandemic has exposed and deepened pre-existing education inequalities that were never adequately addressed. Despite critical additional funding needs, two-thirds of low- and lower-middle-income countries have cut their public education budgets since the start of the pandemic, according to a recent joint report by the World Bank and UNESCO (UNESCO Institute for Statistics Data, 2020). According to Audrey Azoulay, UNESCO Director-General, (Karalis, 2020):

"We are entering uncharted territory and working with countries to find hi-tech, low-tech, and no-tech solutions to assure the continuity of learning".

Additionally, to the Director-General, the British Prime Minister underlined the following (Johnson, 2020):
"Most painfully of all, the costs of school closure have fallen disproportionately on the most disadvantaged, the very children who need school the most. Surveys estimate that while the majority of pupils have been learning at home, as many as a quarter of pupils were doing less than two hours of schoolwork a day. Keeping our schools closed a moment longer than what is absolutely necessary, is socially intolerable, economically unsustainable, and morally indefensible”.

Also, in the past, with the European economic-financial crisis comprising a considerable part of their life trajectories, students who are currently entering university are most likely to be anxious about their individual or parental financial situation (Asselmann et. al., 2020). Having inherited a set of economic, political, and social worries about their financial situation, they are already anxious about their future. Even when students in certain cases overcome their financial problems, adapt efficiently to online learning, and participate actively in the new educational environments, research data showed that there was a lack of enthusiasm (Agung et al., 2020). Emotions and emotional status are a major issue. While the University of Patra's students acknowledged that the university had to close because of the pandemic crisis, their emotional status was strongly negative (75\%). Nevertheless, upon the beginning of electronic classes, the dominant emotions turned into positive ones (95\%) (Karalis \& Raikou, 2020).

Moreover, an important issue in online learning is practice. Laboratory studies cannot be carried out with distance education (Sivrikaya, 2019). Art and Health students also need workshops. Chemistry or Physics students cannot perform their experiments at home. As some of the studies in Art Education or Medical and Health programs will only be carried out in a workshop environment or Clinical trials. Obviously, in both of the above, the dimensions of the course application are one of the biggest problems encountered in the distance education process in times of pandemic (Dilmac, 2020). The preclinical curriculum was transferred online and students completed virtual clinical skill assessments. Specifically, medical education and hospital training may never be the same again as many institutions experienced abrupt disruptions in the face of the pandemic crisis (Wayne et al., 2020).

Researchers and academics tried to understand students' perceptions on distance education during the COVID-19 pandemic and carried out empirical studies in India (Mishra et al., 2020; Naik et al., 2021), Serbia (Bojovic et al., 2020), Pakistan (Malik et al., 2020), USA (Aguilera-Hermida, 2020), South Africa (Armoed, 2021), Poland (Cicha et al., 2021), and elsewhere. According to the relevant literature, technological infrastructure and monetary issues are not the only important factors that differentiate the adaptation of the online learning procedures. As for the negative elements of online education, apart from the technical obstacles that have arisen, they are mainly related to the lack of communication and cooperation, as well as to the general restriction of social contact in the academic context (Karalis \& Raikou, 2020; Lassoued et al., 2020). Bao (2020) in her study for the University of Beijing with a sample of 44,700 subjects notes that the greatest difficulties for students did not come from a lack of technological skills, but from a lack of self-discipline and appropriate learning materials.

Depending on their experience, students differ in the adoption of ICT skills (Mehdar, 2020). For example, as stated by Brown and Czerniewicz (2008) when looking at the case of almost all South African 
students, who were exposed to ICTs, the use of these technologies was rarely frequent and despite the hype associated with Web 2.0 technologies, there was low use of those for teaching and learning. First-year students are responsive and receptive to the use of ICT in a distance learning pedagogical framework, contrary to the answers of students of higher semesters, who prefer the use of traditional teaching methods and they appear opposed to distance learning processes, in which they face communication barriers (Amir et al., 2020). A similar study by Owusu-Fordjour et al. (2020) on a sample of 250 students from Ghana shows the negative impact of distance learning on learning outcomes, as students stated, among other things, that they had limited internet access, did not have the required know-how of using the educational platforms with which even the teaching staff of the universities was not familiar. Similar were the findings of Tsitsia et al. (2020) with the students of this research adding to the limited internet access and the high cost of distance learning. Communication, and more concretely, the absence of interaction between teaching staff and students seems to be one of the main problems (Gokbulu, 2020). Important issues also are the lack of access to internet facilities and the lack of campus socialization as the pedagogical benefits from face-toface communication and personal contact with teaching staff and peers cannot be recreated in the distance learning environment (Adnan \& Anwar, 2020). Also, another common theme in university students' responses was the reference to the feeling of disconnection, the increased feeling of isolation caused by online classes (Al-Twait \& AlSaht, 2020). It should be emphasized here that connectivity is a very important feature in the daily life of students currently entering university. One of the most important effects of this process of connectedness is the multicultural and global conception of everyday life (Mack \& Palley, 2012). A s a result of this feeling of disconnection, students displayed behaviors of losing interest in the class, finding it hard to concentrate, feeling disengaged and finally evaluating themselves as less productive (Yang, 2021). Of particular interest is also research from the United Arab Emirates concerning the extent to which the pandemic has affected the selection of studies by students and their families, with the variables of economic cost, quality of student life and provision of on-line courses appear to be differentiated in relation to the pre-pandemic period (Nanath et al., 2021)

In the past, the debates about the exposure of 'new students' to educational (Maton, 2004) or technological (Hickox \& Moore, 1995) change were common. Not only the university students, but also professors, faced self-imposed obstacles, as well as pedagogical, technical, and financial or organizational obstacles. According to Merriman (2015), the current generation consists of true digital natives. For them, this is a technological world (Mack \& Palley, 2012). While in the midst of this COVID-19 crisis the generation currently entering university is more complex than the literature would lead an observer to expect. In their research concerning the use of technologies, Kennedy et al. (2008) found that amongst first-year Australian students, there was significant diversity when looking beyond the basic and entrenched technologies. Their findings ran counter to the results of Prensky's research, about the characteristics of 'Digital Natives' (Prensky, 2001) and the similar analysis and results by Tapscott $(1998,2008)$.

\section{RESEARCH METHODOLOGY}

\section{Scope and Aims of the Research}

The purpose of the study (research problem) is to detect, describe, and "measure" the attitudes of the student population towards the distance learning process, which was adopted during the pandemic in Greek tertiary education. The aims of the research are, as follows:

1. To record university students' attitudes towards distance education (in general).

2. To record students' attitudes towards the Pedagogical relationship as it arises during distance education.

3. To record students' attitudes towards relationships among students.

4. To record students' attitudes towards Educational Inequalities.

5. To correlate students' attitudes with specific demographics, social interaction of the students, and choices of using the new technologies.

\section{Population and Sampling}

The research population consisted of Greek students studying at University of Athens, Aristotle University of Thessaloniki, University of Ioannina, University of Patras and University of Peloponnese.

Through several educational platforms (e-class, classweb, and ecourse) 2,500 invitations were sent to students to complete the questionnaire, but 807 of them replied after all. The sample is convenient and random and is considered to be large, which ensures representativeness and regularity of its distribution. Besides, the reductions we attempted in the general sets of students do not show significant discrepancies.

\section{Research Method \&Tool}

The current study adopted a quantitative cross section research design. The questionnaire was selected as the most appropriate tool for reviewing and mapping the attitudes of a large number of students in order to record and analyze as many parameters as possible of the terms and conditions of students' work.

In the present research we chose the questionnaire as a research tool for the following reasons:

1. It easily arouses the interest of the respondents and increases the participation in the research process.

2. The initial decision on the need to use a large sample of subjects and the technical capabilities of the research team favors the use of a questionnaire.

3. The questionnaire is used to collect information about perceptions and opinions of subjects, which are not easy to observe.

4. The questionnaire as a research tool allows continuous testing and interventions to be formulated in the most appropriate way.

For the purposes of the study, a questionnaire was structured as a tool for quantitative research of student's attitudes. The questionnaire incorporated Likert scales that cover the research questions. Four stop scales ( 5 points Likert Scales) were created. A face validity check of the scales was performed by 5 independent critical reviewers, two times before the first (pilot) use of the questionnaire to 25 persons. After the 
pilot use, some specific necessary reviews were made according to the results of the preliminary Cronbach's alpha test. After the second pilot use to other 37 persons, the questionnaire was distributed through Moodle platforms (e-course, e-class) of university courses to the five Greek universities.

The research tool as mentioned above is consisted by 6 parts:

1. Demographic and social characteristics of the sample (11 questions)

2. The use of personal computers (6 questions)

3. Scale A: Distance education (16 items)

4. Scale B: Pedagogical relationship (9 items)

5. Scale C: Relationships among students (8 items)

6. Scale D: Educational Inequalities (9 items)

A validation process was followed for each scale in which 15 experts were involved. For this reason, the followings were calculated (Zamanzadeh et al. 2014):

1. Necessity of items (CVR),

2. Relevancy of items (I-CVIs and S-CVI),

3. Clarity of items (I-CVIs).

4. Finally, Cohen's Kappa was computed by using the following equation (Cohen, 1960; Scott, 1955; Uebersax, 1987; Strijbos et al., 2006; Smeeton, 1985):

$$
\mathrm{K}=(\mathrm{I}-\mathrm{CVI}-\mathrm{Pc}) /(1-\mathrm{Pc})
$$

In order to calculate the modified Kappa statistic, we used the following equation:

$$
\mathrm{Pc}=[\mathrm{N} ! / \mathrm{A} !(\mathrm{N}-\mathrm{A} !)] \times 0.5^{\mathrm{N}}
$$

The kappa statistic value is .81 .

\section{Data Analysis}

Data were analyzed using IBM SPSS Statistics v. 25 and both descriptive and inductive statistics were used. To examine the effect of demographic factors as well as data collection questions, on the degree of agreement-satisfaction expressed by the subjects, t-test and ANOVA were used accordingly.

\section{Moral and Ethical Issues}

During the investigation, certain rules were followed. Primarily, the information about the real purpose of the investigation was avoided to be distorted. In addition, the following were avoided: the involution of the participants without being previously informed about the research, their compulsion to participate, their exposure to stressful situations, but also any violation of their privacy (Robson \& McCartan, 2016). Therefore, the practices used at all stages of the research process are characterized by ethics and adherence to international practice regarding scientific research ethics.

\section{The Sample}

The 807 students of the research were distributed regarding their gender, the field, the year and level of their studies, the educational level of their parents and their place of residence. Table 1 shows the characteristics of the sample. Table 2 shows the sample's computer use.

\begin{tabular}{|c|c|c|}
\hline & $\mathbf{f}$ & $\%$ \\
\hline \multicolumn{3}{|l|}{ Gender } \\
\hline Male & 164 & 20.3 \\
\hline Female & 643 & 79.7 \\
\hline \multicolumn{3}{|l|}{ Level of studies } \\
\hline Undergraduate & 686 & 85.0 \\
\hline Postgraduate & 121 & 15.0 \\
\hline \multicolumn{3}{|l|}{ Father's education } \\
\hline Primary school graduate & 133 & 16.5 \\
\hline Secondary education graduate & 300 & 37.2 \\
\hline Tertiary education graduate & 313 & 38.8 \\
\hline Postgraduate diploma & 61 & 7.6 \\
\hline \multicolumn{3}{|l|}{ Mother's education } \\
\hline Primary school graduate & 70 & 8.7 \\
\hline Secondary education graduate & 312 & 38.7 \\
\hline Tertiary education graduate & 376 & 46.6 \\
\hline Postgraduate diploma & 49 & 6.1 \\
\hline \multicolumn{3}{|l|}{ Field of study } \\
\hline Humanities & 493 & 61.1 \\
\hline Social studies & 94 & 11.6 \\
\hline Science & 88 & 10.9 \\
\hline Technology & 82 & 10.2 \\
\hline \multicolumn{3}{|l|}{ Residence } \\
\hline Athens-Thessaloniki & 314 & 38.9 \\
\hline Urban area & 201 & 24.9 \\
\hline Large village & 162 & 20.1 \\
\hline Rural area & 130 & 16.1 \\
\hline \multicolumn{3}{|l|}{ Year of studies } \\
\hline $1-2$ year & 337 & 41.8 \\
\hline 3-4 year & 329 & 40.8 \\
\hline$>5$ th year & 141 & 17.5 \\
\hline
\end{tabular}

Table 1. Demographic and social characteristics of the sample

Table 2. The use of personal computers

\begin{tabular}{lcc}
\hline \multicolumn{1}{l}{ f } & $\%$ \\
\hline Is there at least one computer at your residence? & & \\
\hline Yes & 804 & 99.6 \\
\hline No & 3 & 0.4 \\
\hline $\begin{array}{l}\text { Do you have any reservations/ doubts about } \\
\text { computers in education? }\end{array}$ & & \\
\hline Yes & 283 & 35.1 \\
\hline No & 370 & 45.8 \\
\hline
\end{tabular}

\section{RESULTS}

The four scales of our research were constructed in order to measure the level of agreement on distance education in general and its main disadvantages as they are being described at the relevant literature (Coman et al. 2020; Ferri et al., 2020; Hassenburg, 2009; Jara \& Mellar, 2007; Lozovoy \& Zashchitina, 2019; Simonson et al. 2012; Sokolova et al. 2018; Xu \& Jaggars, 2010). On that basis, the scales reflect the main negative characteristics of distance education, focusing on the experience that university students had while studying remotely during COVID-19 pandemic. University students, actually, express their agreement considering these general negative characteristics. Table 3 shows Cronbachs' alpha test for each scale. As we can see from Table 4 , the mean of each scale is over 3.5 and especially for the scales $C$ and $\mathrm{D}$ the means of agreement reach the value 4 , which should be considered as relatively high. The means of the A and B scales are over 
Table 3. Demographic and social characteristics of the sample

\begin{tabular}{ccc}
\hline Scale's Code & Name of the scale & Cronbachs' alpha \\
\hline A & Distance education & 0.822 \\
\hline B & Pedagogical relationship & 0.914 \\
\hline C & Relationships among students & 0.818 \\
\hline D & Educational Inequalities & 0.877 \\
\hline
\end{tabular}

Table 4. The use of personal computers

\begin{tabular}{cccc}
\hline Scale's Code & Name of the scale & Mean & S.D. \\
\hline A & Distance education & 3.5678 & .61813 \\
\hline B & Pedagogical relationship & 3.7169 & .91281 \\
\hline C & Relationships among students & 3.9216 & .71643 \\
\hline D & Educational Inequalities & 3.9357 & .78032 \\
\hline
\end{tabular}

Table 5. Highest means of the A scale

\begin{tabular}{ccc}
\hline Scale's code & Name of the scale & Cronbachs' alpha \\
\hline A & Distance education & 0.822 \\
\hline B & Pedagogical relationship & 0.914 \\
\hline C & Relationships among students & 0.818 \\
\hline D & Educational inequalities & 0.877 \\
\hline
\end{tabular}

Table 6. The use of personal computers

\begin{tabular}{cccc}
\hline Code & Statement & Mean & S.D. \\
\hline B.1 & I prefer to communicate with my teachers face to face & 4.14 & 1.101 \\
\hline B.3 & $\begin{array}{c}\text { Socialization - a basic function of education - is not } \\
\text { achieved through the use of distance learning }\end{array}$ & 4.19 & 1.005 \\
\hline B.5 & $\begin{array}{c}\text { The pedagogical relationship as it develops with face-to- } \\
\text { face teaching cannot be replaced by distance }\end{array}$ & 4.22 & 1.038 \\
\hline
\end{tabular}

Table 7. Highest means of the C scale

\begin{tabular}{cccc}
\hline Code & Statement & Mean & S.D. \\
\hline C. 2 & $\begin{array}{c}\text { Online courses do not develop relationships between } \\
\text { students, which can evolve into friendships. }\end{array}$ & 4.12 & 1.131 \\
\hline C.6 & $\begin{array}{c}\text { Distance education degrades the general socializing } \\
\text { function of university education }\end{array}$ & 4.27 & 0.945 \\
\hline C.8 & $\begin{array}{c}\text { Distance education has deprived many students of even } \\
\text { the first contact with the university }\end{array}$ & 4.72 & 0.650 \\
\hline
\end{tabular}

Table 8. The use of personal computers

\begin{tabular}{lccc}
\hline Code & Statement & Mean & S.D. \\
\hline D.8 & The available equipment creates inequalities between & 4.12 & 1.037 \\
students & Students who have a secluded and comfortable space at \\
h.1 & 4.41 & 0.913 \\
\hline D.2 & $\begin{array}{c}\text { Students who have an advantage over those who do not } \\
\text { superior to those who do not }\end{array}$ & 4.62 & 0.753 \\
\hline
\end{tabular}

the means of the scale and show that university students express a not strong but meaningful degree of agreement.

Consolidated, the statements with the highest degree of agreement, as the Table 5, Table 6, Table 7, and Table 8 indicate, are:

For scale A (distance education):

A.16 Distance education has degraded laboratory training (4.19/5).

Respectively, for scale B (pedagogical relationship):

B.5. The pedagogical relationship as it develops with face-to-face teaching cannot be replaced by distance (4.22/5),

B.3 Socialization - a basic function of education - is not achieved through the use of distance learning (4.19/5), and
A.8 Not all types of courses can be taught remotely (4.46/5),

A.4 Face to face teaching cannot be replaced by distance learning $(4.31 / 5)$,

A.5 Conventional lectures on university premises create a better academic climate than distance education (4.23/5), and

B.1 I prefer to communicate with my teachers face to face (4.14/5).

Regarding scale C (relationships among students):

C.8 Distance education has deprived many students of even the first contact with the university $(4.72 / 5)$,

C.6. Distance education degrades the general socializing function of university education (4.27/5), and

C.2 Online courses do not develop relationships between students, which can develop into friendships (4.12/5).

Finally, about scale D:

D.2 Students who have the proper equipment at home are superior to those who do not (4.62/5),

D.1 Students who have a secluded and comfortable space at home have an advantage over those who do not (4.41/5), and

D.8 The available equipment creates inequalities between students $(4.12 / 5)$.

The t-test for the effect of gender on the responses of the subjects shows a small but statistically significant correlation for the responses of scale D (educational inequalities) where women seem to express a greater degree of agreement than men.

According to the ANOVA Analysis using the Bonferroni Post Hoc Test, statistically significant differences were noticed between the subjects depending on their demographic and social characteristics. More specifically, the set of answers in the first 4 scales seems to be influenced by the attitude of the subjects towards the introduction of computers in education (Mean A: df:2 \& $\mathrm{p}<0.01$, Mean B: df: 2 \& $\mathrm{p}<0.01$, Mean C: df:2 \& $p<0.01$, Mean D: df:2 \& $p<0.01$ ). Thoroughly, those who are skeptical about the introduction of computers in education show a greater degree of agreement, across the four scales, than those who seem to be well disposed towards this possibility (Scale A: MD (Mean Difference): $0.56351 \& \mathrm{p}<0.01$, Scale B: MD: $0.61022 \& \mathrm{p}<0.01$, Scale C: MD: $0.43180 \& \mathrm{p}<0.01$, Scale D: MD: $0.42235 \& \mathrm{p}<0.01$ ). Also remarkable is that the year of study seems to play an important role in terms of subjects' answers (Mean A: df:2 \& $\mathrm{p}<0.01$, Mean B: df:2 \& $\mathrm{p}<0.01$, Mean C: df: 2 \& $\mathrm{p}<0.01$, Mean D: df:2 \& $\mathrm{p}<0.01$ ), since, across the four scales, the first and second year students show a greater degree of agreement in comparison with the older ones (Scale A: MD: 0.23599 \& $p<0.01 \&$ MD: 0.34693 \& $p<0.01$, Scale B: MD: $0.6932 \& \mathrm{p}<0.01 \&$ MD: $0.8971 \& p<0.01$, Scale C: MD: $0.5498 \& \mathrm{p}<0.05 \&$ MD: $0.7114 \&$ $\mathrm{p}<0.05$, Scale D: MD: $0.5968 \& \mathrm{p}<0.01 \&$ MD: $0.7723 \& \mathrm{p}<0.05)$.

Worthy of attention is that in scale $\mathrm{D}$ (educational inequalities) it seems that the field of study is an influential factor (df: $4 \& \mathrm{p}<0.01$ ), as those who study humanities, show a higher degree of agreement than the ones who study science (MD: $0.28116 \& \mathrm{p}<0.05$ ) or technology (MD: $0.326338 \& \mathrm{p}<0.05$ ). Furthermore, the frequency of computer use also appears to affect samples' responses $(\mathrm{df}: 3 \& \mathrm{p}<0.01)$ in Scale A (distance education) (df:3 \& $\mathrm{p}<0.01)$, as those who use the computer a few times a week show a greater degree of agreement than those who use the computer daily (MD: $0.7488 \& \mathrm{p}<0.05$ ), or even several hours per day (MD: $0.7333 \& \mathrm{p}<0.01$ ). Finally, the ideological position of the subjects seems to influence their answers on scale 4 - educational 
inequalities (df:4 \& p $<0.01$ ). More specifically, those who stated that they ideologically belong to the Left wing show a greater degree of agreement than those who belong to the Right wing (MD: 0.47641 \& $\mathrm{p}<0.01)$ and the Center (MD: $0.33901 \& \mathrm{p}<0.01$ ), while those of the subjects who claimed that they are anarchists show a greater degree of agreement than those who stated that they ideologically belong to the Right-wing parties (MD: $0.41603 \& \mathrm{p}<0.05)$.

\section{DISCUSSION}

Living in times of the pandemic, apart from the devastating health consequences, the COVID-19 crisis has immediate economic and social effects on the lives and studies of higher education students. Hence, the increasing interest of researchers to examine how it has affected their daily lives, including teaching and learning, social contacts, as well as how students are coping with the situation emotionally in different parts of the world.

According to the Dell Technologies survey $(12,000$ secondary and post-secondary students), those who were born after the mid-1990s, bring new tech skills and high expectations. They use technology as part of their formal education (98\%), say that technology literacy matters (97\%), believe that technology and automation will create a more equitable work environment (80\%), and rank their technological literacy as good or excellent (73\%) (Dimensional Research, 2018).

Relevant studies in Greece revealed that most of the first-year Greek students widely use technological media they have grown up with new digital technologies. Nevertheless, research results indicate that technological infrastructure and financial issues impinge on students' attendance and engagement (OECD, 2020).

The circumstances created due to COVID-19, the pandemic crisis, have posed an unprecedented challenge to educational systems and the global higher education sector (Crawford et.al., 2020). Over 100 million teachers and school personnel were impacted by the sudden closures of learning institutions. The complete or partial closure of University institutions due to COVID-19 led to social distance.

Unavoidable during the pandemic crisis, students use more than before digital and networking technologies for learning. Consequently, the digital transformation to remote teaching and digital classrooms raised a variety of issues on quality, social interaction, and data protection. Moreover, a new field that needs to be carefully discussed and tackled has emerged.

Given that the pandemic crisis (COVID-19) has substantial effects on education, we attempted to explore important phenomena such as technical, pedagogical, and financial or organizational issues. According to Adnan and Anwar (2020), students' adaptation to distance learning under the pressure of the pandemic crisis, cannot be effective in countries where the vast majority of students do not have access to the internet due to technical, pedagogical, and financial or organizational difficulties. As we have already mentioned and even more importantly, technological infrastructure and financial issues are not the only issues that differentiate the adaptation of the online learning procedures. Our data analysis in line with Cameron et al. (2021) and Karalis and Raikou (2020), indicates the lack of communication and cooperation, as well as the general restriction of social contact in the academic context as some of the major obstacles.
According to our data, the pandemic has exposed and deepened preexisting education inequalities, as there are statistically significant differences between the subjects depending on their demographic and social characteristics (Kyridis, 1996, 2003; Kyridis et al., 2011). The sample's responses in scale Educational inequalities show a small but statistically significant difference that depends on gender. More precisely women seem to express a greater degree of agreement than men.

As we have already pointed out COVID-19 can bring about a digital divide, assuming that the pandemic is more likely to accelerate and reshape existing phenomena rather than creating new ones. Freshmen are already anxious about their future. It is noteworthy to mention that our data analysis indicates that students who are skeptical about the introduction of computers in education show a greater degree of agreement on all 4 scales than those who say they are positive in this possibility.

Also, the ideological position of the sample seems to influence their answers on scale 4 (educational inequalities). To be specific, those who stated that they ideologically belong to the Left-wing, show a greater degree of agreement than those who belong to the Right-wing. Furthermore, according to Agung et al. (2020), even when students in certain cases overcome their financial problems, adapt efficiently to online learning, and participate actively in a big percentage, research data showed that there was a lack of enthusiasm.

Finally, the year of study seems to play an important role in the sample's answers. According to Mehdar's research (2008), depending on their experience, students differ in the adoption of ICT. As stated by Amir (2020) and Brown and Czerniewicz (2008), first-year students are responsive and receptive to the use of ICT in a distance learning pedagogical framework contrary to the answers of students of higher semesters who prefer the use of traditional teaching methods and opposed to distance learning processes, in which they face communication barriers. Also, in accordance with the data of the above surveys, in our analysis, the first and second-year students show a greater degree of agreement in comparison with the older students.

As a conclusion, from the above presented findings and the literary review, it becomes evident that learning and social obstacles were raised in the academic environment by the uncertain situation that the pandemic crisis created. The remarks above convey a sense of urgency within the academy that pressures students to keep up with changes and raises concerns that some students may be left behind. In any case, the closure of university institutions, as the main precaution that was taken, created new economic, social and educational phenomena and difficulties that had to be explored in order to overcome obstacles and continue the educational activity.

Author contributions: All authors were involved in concept, design, collection of data, interpretation, writing, and critically revising the article. All authors approve final version of the article.

Funding: The authors received no financial support for the research and/or authorship of this article.

Declaration of interest: Authors declare no competing interest.

Data availability: Data generated or analysed during this study are available from the authors on request. 


\section{REFERENCES}

Adnan, M., \& Anwar, K. (2020). Online learning amid the COVID-19 pandemic: Students' perspectives. Journal of Pedagogical Sociology and Psychology, 2(1), 45-51. http://www.doi.org/10.33902/ JPSP.\%202020261309

Aguilera-Hermida, A. P. (2020). College students' use and acceptance of emergency online learning due to COVID-19. International Journal of Educational Research Open, 1, 100011. https://doi.org/10.1016/ j.ijedro.2020.100011

Agung, A. S. N., Surtikanti, M. W., \& Quinones, C. A. (2020). Students' perception of online learning during COVID-19 pandemic: A case study on the English students of STKIP Pamane Talino. Soshum: Journal of Social Sciences and Humanities, 10(2), 225-235. https://doi.org/10.31940/soshum.v10i2.1316

Alawamleh, M., Al-Twait, L. M., \& Al-Saht, G. R. (2020). The effect of online learning on communication between instructors and students during COVID-19 pandemic. Asian Education and Development Studies. https://doi.org/10.1108/AEDS-06-2020-0131

Amir, L. R., Tanti, I., Maharani, D. A., Wimardhani, Y. S., Vera, J., Benso, S., \& Puspitawati, R. (2020). Student perspective of classroom and distance learning during COVID-19 pandemic in the undergraduate dental study program Universitas Indonesia. BMC Medical Education, 20, 1-8. https://doi.org/10.1186/s12909-02002312-0

Aristovnik, A. Keržič, D., Ravšelj, D., Tomaževič, N., \& Umek, L. (2020). Impacts of the COVID-19 pandemic on life of higher education students: A global perspective. Sustainability, 12, 8438. https://doi.org/10.20944/preprints202008.0246.v2

Armoed, Z. (2021, February). The COVID-19 pandemic: Online teaching and learning at higher education institutes. IOP Conference Series: Earth and Environmental Science, 654(1), p. 012026). https://doi.org/10.1088/1755-1315/654/1/012026

Asselmann, E., Borghans, L., Montizaan, R., \& Seegers, P. (2020). The role of personality in the thoughts, feelings, and behaviors of students in Germany during the first weeks of the COVID-19 pandemic. PLoS ONE, 15(11). https://doi.org/10.1371/journal. pone.0242904

Bao, W. (2020). COVID-19 and online teaching in higher education: A case study of Peking University. Human Behaviour \& Emergency Technologies, 2, 113-115. https://doi.org/10.1002/hbe2.191

Bauman, Z. (2000) Liquid modernity. Polity.

Bojović, Ž., Bojović, P. D., Vujošević, D., \& Šuh, J. (2020). Education in times of crisis: Rapid transition to distance learning. Computer Applications in Engineering Education, 28(6), 1467-1489. https://doi.org/10.1002/cae.22318

Breslin, T. (2021). Lessons from lockdown: The educational legacy of COVID-19. Routledge. https://doi.org/10.1002/cae.22318

Brown C., \& Czerniewicz L. (2008). Trends in student use of ICTs in higher education in South Africa. 10th Annual Conference on World Wide Web Applications.

Cameron, M. P., Fogarty-Perry, B., \& Piercy, G. (2021). The impacts of the COVID-19 pandemic on higher education students in New Zealand. Working Papers in Economics 21/02, University of Waikato. https://ideas.repec.org/p/wai/econwp/21-02.html
Carifio, J., \& Perla, R. J. (2007). Ten common misunderstandings, misconceptions, persistent myths and urban legends about Likert scales and Likert response formats and their antidotes. Journal of Social Sciences, 3(3), 106-116. https://doi.org/10.3844/ jssp.2007.106.116

Cicha, K., Rizun, M., Rutecka, P., Strzelecki, A. (2021). COVID-19 and higher education: First-year students' expectations toward distance learning. Sustainability, 13(4), 1889. https://doi.org/10.3390/ su13041889

Cohen, J. (1960). A coefficient of agreement for nominal scales. Educational and Psychological Measurement, 1(20), 37-46. https://doi.org/10.1177/001316446002000104

Coman, C., Țîru, L. G., Meseșan-Schmitz, L., Stanciu, C., \& Bularca, M. C. (2020). Online teaching and learning in higher education during the Coronavirus pandemic: Students' perspective. Sustainability, 12(24), 1-24. https://doi.org/10.3390/su122410367

Crawford, J., Butler-Henderson, K., Rudolph, J., Malkawi, B., Glowatz, M., Burton, R., Magni, P. A., \& Lam, S. (2020). COVID-19: 20 countries' higher education intra-period digital pedagogy responses. Journal of Applied Learning \& Teaching, 3(1), 9-28. https://doi.org/10.37074/jalt.2020.3.1.7

Davidson, J. (1970). Outdoor recreation surveys: The design and the use of questionnaires for site surveys. Countryside Commission.

Dhawan, S. (2020). Online learning: A Panacea in the time of COVID19 crisis. Journal of Educational Technology Systems, 49(1), 5-22. http://doi.org/10.1177/0047239520934018

Dilma, S. (2020) Students' opinions about the distance education to Art and Design Courses in the pandemic process. World Journal of Education, 10(3), 113-126. https://doi.org/10.5430/wje.v10n3p113

Dimensional Research (2018). The future has arrived, are you ready for gen $z$ ? Round Rock: Dell. https://www.dellemc.com/enus/collaterals/unauth/salesdocuments/solutions/gen-z-thefuture-has-arrived-executive-summary.pdf

Ferraro, F. V., Ambra, F. I., Aruta, L., \& Iavarone, M. L. (2020). Distance learning in the COVID-19 era: Perceptions in Southern Italy. Education Sciences, 10(12), 1-10. http://doi.org/10.3390/ educsci10120355

Ferri, F., Grifoni, P., Guzzo, T. (2020). Online learning and emergency remote teaching: Opportunities and challenges in emergency situations. Societies, 10(4), 86. https://doi.org/10.3390/soc10040086

Foti, P. (2020). Research in distance learning in Greek kindergarten schools during the pandemic of COVID-19: Possibilities, dilemmas, limitations. European Journal of Open Education and E-learning Studies, 5(1), 19-40. https://doi.org/10.5281/zenodo.3839063

Fraise, P., \& Piaget, J. (1973). Traite de psychologie experimentale [It is about experimental psychology]. Presses Universitaires de FrancePUF.

Gokbulut, B. (2020). Distance education students' opinions on distance education. In M. Durnali, \& I. Limon (Eds.), Enriching teaching and learning environments with contemporary technologies (pp. 138-152). https://doi.org/10.4018/978-1-7998-3383-3.ch008

Hassenburg, A. (2009). Distance education versus the traditional classroom. Berkeley Scientific Journal, 13(1), 7-10. https://doi.org/10.5070/BS3131007609 
Hickox, M., \& Moore, R. (1995). Liberal-humanist education: The vocationalist challenge. Curriculum Studies, 3(1), 45-59. https://doi.org/10.1080/0965975950030103

Jara, M., \& Mellar, H. (2007). Exploring the mechanisms for assuring quality of e-learning courses in UK higher education institutions. European Journal of Open, Distance and E-Learning, 2007(1), 1-14.

Javeau, J. (1996). Research with questionnaire. Dardanos.

Johns, R. (2005). One size doesn't fit all: Selecting response scales for attitude items. Journal of Elections. Public Opinion and Parties,15(2), 237-264. https://doi.org/10.1080/13689880500178849

Johnson, B. (2020). Keeping our schools closed a moment longer than is absolutely necessary is socially intolerable, economically unsustainable and morally indefensible. https://www.dailymail. co.uk/debate/article-8607987/BORIS-JOHNSON-Keepingschools-closed-longer-necessary-intolerable.html

Jones, C., Ramanau, R., Cross, S., \& Healing, G. (2010). Net generation or Digital natives: Is there a distinct new generation entering university? Computers \& Education, 54(3), 722-732. https://doi.org/10.1016/j.compedu.2009.09.022

Karalis, T. (2020). Planning and evaluation during educational disruption: Lessons learned from COVID-19 pandemic for treatment of emergencies in education. European Journal of Education Studies, 7(4), 125-142. https://doi.org/10.5281/zenodo.3789022

Karalis, T., \& Raikou, N. (2020). Teaching at the times of COVID-19: Inferences and implications for higher education pedagogy. International Journal of Academic Research in Business and Social Sciences, 10(5), 479-493. https://doi.org/10.6007/IJARBSS/v10i5/7219

Kennedy, G. E., Judd, T., Churchward, A., \& Gray, K. (2008). First year students' experiences with technology: Are they really digital natives? Australian Journal of Educational Technology, 24(1), 108-122. https://doi.org/10.14742/ajet.1233

Kyridis, A. (1996). Educational inequality. Kyriakidis.

Kyridis, A. (2003). Inequality in Greek education and access to university (1955-1985). Gutenberg.

Kyridis, A., Tsakiridou, H., Zagkos, C., Koutouzis, M., \& Tziamtzi, C. (2011). Educational inequalities and school dropout in Greece. A regional issue. International Journal of Education, 3(2), 1-15. https://doi.org/10.5296/ije.v3i2.855

Lassoued, Z., Alhendawi, M., \& Bashitialshaaer, R. (2020). An exploratory study of the obstacles for achieving quality in distance learning during the COVID-19 pandemic. Universal Journal of Educational Research, 10(9), 220-232. https://doi.org/10.3390/ educsci10090232

Lozovoy, A. Y., \& Zashchitina, E. K. (2019). Online education: Pros and cons. In S. Shaposhnikov (Ed.) 2019 International Conference "Quality Management, Transport and Information Security, Information Technologies", (pp. 631-633). https://doi.org/10.1109/ ITQMIS.2019.8928455

Mack \& Palley (2012). Gen Z. Digital in their DNA. N.Y: JWT. https://doi.org/10.1016/j.gene.2012.03.044

Malik, F., Ajmal, F., \& Jumani, Z. (2020). The effects of COVID-19 on education in Pakistan: Students' perspective. International Journal of Distance Education and E-Learning, 6(1), 217-234. https://doi.org/10.36261/ijdeel.v6i1.1431
Maton, K. (2004). The wrong kind of knower: Education, expansion and the epistemic device. In J. Mullew, B. Davies, \& A. Morais (Eds.), Reading bernstein, researching bernstein (218-231). Routledge.

Mehdar, K. M. (2020). Students' attitudes as regard to distance learning of anatomy courses throughout COVID-19 pandemic lockdown period among medicine and paramedical faculties of Najran University, Saudi Arabia. Universal Journal of Educational Research, 8(11), 6166-6172. https://doi.org/10.13189/ujer.2020.082253

Merriman, M. (2015). What if the next big disruptor isn't a what but a who? Gen $\mathrm{Z}$ is connected, informed, and ready for business Ernst \& Young. https://assets.ey.com/content/dam/ey-sites/ey-com/en_gl /topics/digital/ey-rise-of-gen-z-new-challenge-for-retailers.pdf

Mishra, L., Gupta, T., \& Shree, A. (2020). Online teaching-learning in higher education during lockdown period of COVID-19 pandemic. International Journal of Educational Research Open, 1, 100012. https://doi.org/10.1016/j.ijedro.2020.100012

Naik, G. L., Deshpande, M., Shivananda, D. C., Ajey, C. P., \& Manjunath Patel, G. C. (2021). Online teaching and learning of higher education in India during COVID-19 emergency lockdown. Pedagogical Research, 6(1). https://doi.org/10.29333/pr/9665

Nanath, K., Sajjad, A., \& Kaitheri, S. (2021). Decision-making system for higher education university selection: Comparison of priorities pre-and post-COVID-19. Journal of Applied Research in Higher Education. https://doi.org/10.1108/JARHE-08-2020-0277

OECD. (2020). Education Policy Outlook: Greece. https://www.oecd.org/education/policy-outlook

Owusu-Fordjour, C., Koomson, C. K., \& Hanson, D. (2020). The impact of COVID-19 on learning-the perspective of the Ghanaian student. European Journal of Education Studies, 7(3), 88-101. https://doi.org/10.5281/zenodo.3753586

Prensky, M. (2001). Digital natives, digital immigrants. On the Horizon, 9(5), $1-6$.

Robson, C., \& McCartan, K. (2016). Real world research. Wiley.

Rotas, E., \& Cahapay, M. B. (2020). Difficulties in remote learning: Voices of Philippine university students in the wake of COVID-19 crisis. Asian Journal of Distance Education, 15(2), 147-158. https://doi.org/10.5281/zenodo.4299835

Sahbaz, A. (2020). Views and evaluations of university students about distance education during the COVID-19 pandemic. EDUPIJ, 9(3), 185-198. https://doi.org/10.22521/edupij.2020.93.5

Scott, W. (1955). Reliability of content analysis: The case of nominal scale coding. Public Opinion Quarterly, 17, 321-325. https://doi.org/10.1086/266577

Serhan, D. (2020). Transitioning from face-to-face to remote learning: Students' attitudes and perceptions of using Zoom during COVID19 pandemic. International Journal of Technology in Education and Science, 4(4), 335-342. https://doi.org/10.46328/ijtes.v4i4.148

Simonson, M., Smaldino, S., Albright, M., \& Zvacek, S. (2012). Teaching and learning at a distance: Foundations of distance education ( $5^{\text {th }}$ ed.). Pearson.

Sivrikaya, O. S. (2019). Chemistry students' opinions about taking chemistry education as distance education. European Journal of Open Education and E-learning Studies, 4(2), 35-45. https://doi.org/10.5281/zenodo.3592897 
Smeeton, N. C. (1985). Early history of the Kappa statistic. Biometrics, 41(3), 795.

Sokolova, N. A., Pylkin, A. A., Stroganova, O. A., \& Antonian, K. G. (2018). The pros and cons of distance learning. In V. Chernyavskay \& H. Kuße (Eds.), 18th Professional Culture of the Specialist of the Future Conference (pp. 1478-1486). https://doi.org/10.15405/ epsbs.2018.12.02.157

Strijbos, J., Martens, R., Prins, F., \& Jochems, W. (2006). Content analysis: What are they talking about? Computers $\&$ Education, 46, 2948. https://doi.org/10.1016/j.compedu.2005.04.002

Tapscott, D. (1998). Growing up digital: The rise of the Net generation. McGraw Hill.

Tapscott, D. (2008). Grown up digital: How the Net generation is changing your world. McGraw-Hill.

Tourangeau, R., Rips, L. J., \& Rasinski, K. A. (2000). The psychology of survey response. Cambridge University Press. https://doi.org/ 10.1017/CBO9780511819322

Tsitsia, B. Y., Kabbah, S. K., Doyi, V., Kabe, S. K., \& Safo, P. (2020). Colleges of education student-teachers'perceptions on the elearning in the era of COVID-19 pandemic. European Journal of Education Studies, 7(12). https://doi.org/10.46827/ejes.v7i12.3455
Uebersax, J. S. (1987). Diversity of decision-making models and the measurement of interrater agreement. Psychological Bulletin, 101(1), 140-146. https://doi.org/10.1037/0033-2909.101.1.140

UNESCO Institute for Statistics Data. (2020). COVID-19 impact on education. https://en.unesco.org/covid19

UNESCO. (n.d.). COVID-19 education response. https://en.unesco.org/ covid19/educationresponse/globalcoalition

Wayne, D. W., Green, M., \& Neilson E. G. (2020). Medical education in the time of COVID-19. Science Advances, 6(31). https://doi.org/10.1126/sciadv.abc7110

Xu, D., \& Jaggars, S. S. (2010). The effectiveness of distance education in Virginia's community colleges: Evidence from introductory college-level math and English courses. Educational Evaluation and Policy Analysis, 33(3), 360-377. https://doi.org/10.3102/ 0162373711413814

Yang, L. H. (2021). Online learning experiences of Irish university students during the COVID-19 pandemic. All Ireland Journal of Higher Education, 13(1).

Zamanzadeh, V., Rassouli M., Abbaszadeh A., Majd, H. A., Nikanfar, A., \& Ghahramanian, A. (2014). Details of content validity and objectifying it in instrument development. Nursing Practice Today, 1(3), 163-171. 